\title{
$\mathrm{RC}$ 벽식 부분구조의 반복 횡하중 거동에서의 축소모델 상사성 실험연구
}

\author{
이한선 ${ }^{1) *} \cdot$ 조창석 ${ }^{1)} \cdot$ 이상호 ${ }^{2)} \cdot$ 오상훈 $^{2)} \cdot$ 박홍근 $^{3)}$ \\ ${ }^{1)}$ 고려대학교 건축사회환경공학부 ${ }^{2)}$ 부산대학교 건축학부 ${ }^{31}$ 서울대학교 건축학부
}

\section{Experimental Study on the Similitude of Small-Scale Models in Cyclic Lateral Behaviors of RC Shear Wall Subassemblages}

\author{
Han-Seon Lee, ${ }^{1) *}$ Chang-Seok Cho, ${ }^{1)}$ Sang-Ho Lee, ${ }^{2)}$ Sang-Hoon Oh, ${ }^{2)}$ and Hong-Gun Park ${ }^{3)}$ \\ ${ }^{1)}$ School of Civil, Environmental and Architectural Engineering, Korea University, Seoul 136-713, Korea \\ ${ }^{2)}$ Dept. of Architectural Engineering, Busan National University, Busan 609-735, Korea \\ ${ }^{3}$ Dept. of Architecture and Architectural Engineering, Seoul National University, Seoul 151-742, Korea
}

\begin{abstract}
For earthquake simulation test it is essential to make sure the similitude in behaviors between the full scale prototype and the reduced scale model. This paper presents the test results obtained through the cyclic lateral-force test, on two-story $\mathrm{RC}$ wall subassemblages. A lower 2-story portion of the prototype structure was selected as subassemblages. The global behavior such as the strength and ductility, and the local behavior such as flexural, shear and uplift deformation were measured. The test results of the $3: 5$ scale specimens representing the prototype were compared with those of $1: 7$ scale models. Two types of subassemblages were used: One with lintel beams and one without lintel beams. The comparison shows that $1: 7$ scale model simulated in general successfully the global and local behaviors of the prototype.
\end{abstract}

Keywords : small scale model, similitude, reinforcement concrete, shear wall, lintel beam

\section{1. 서 론}

우리나라에서 $\mathrm{RC}$ 공동 주택의 수가 전체 주택수에서 차지하는 비율은 $52 \%$ 를 초과하고 있다. ${ }^{1}$ 이러한 고층 공 동주택은 대부분 $\mathrm{RC}$ 벽식 구조를 이루고 있으며, 이는 우 리나라만의 독특한 방식이므로 국제적으로 연구가 부족 한 상태이고, 지진피해 시 이에 대한 안전 및 재사용 판 단기준도 수립되어있지 않다. 따라서 이러한 벽식 $\mathrm{RC}$ 구 조물의 지진반응을 관찰하고 그에 따라 내진 설계기준 및 안전진단 및 보수 보강 기준을 수립하기 위해 실제 지진을 이용한 지진모의 실험을 수행하는 것이 가장 바 람직하다. 이러한 지진모의실험을 우리나라에서 가용한 실험장치 (예로서 부산대 지진실험센터)를 위해서는 축 소모델을 사용하는 것이 불가피하다. 따라서 $\mathrm{RC}$ 구조물 의 축소모델을 사용할 경우, 이 모델이 실물크기의 구조 거동을 잘 모사하는지의 상사성 확보가 요구된다. 이러 한 상사성 연구는 이미 재료의 상사성, ${ }^{2}$ 보나 기둥 등 구조요소에 관한 상사성, ${ }^{3)}$ 골조에 대한 상사성 연구 ${ }^{4)}$ 등 국내·외적으로 다수 수행 되었으나, $\mathrm{RC}$ 벽체의 상사성

*Corresponding author E-mail : hslee@korea.ac.kr Received July 23, 2010, Revised August 27, 2010, Accepted August 30, 2010

(C) 2010 by Korea Concrete Institute
에 관한 연구는 국내 - 외적으로 매우 부족한 형편이다. 따라서 이 연구는 이러한 $\mathrm{RC}$ 벽식구조의 축소모델이 어 느 정도 실물크기 구조물의 구조거동을 잘 모사하는지 실험적으로 확인하고자 하는 것을 목표로 한다.

\section{2. 실험체 설계 및 제작}

실험을 위한 표준대상건물은 아파트 주거 환경 통계 ${ }^{5)}$ 를 이용하여 국내의 가장 전형적인 형태의 모델을 선정 하였으며, 한 세대의 규모가 $89 \mathrm{~m}^{2}$ 이고 2세대가 한 층을 이루는 15 층 판상형의 철근콘크리트 고층 공동주택이다. 실험 대상은 아파트 평면에서 개구부를 가지는 2 층 부 분구조를 Fig. 1과 같이 추출하고 그의 실물크기 상세는 Fig. 2에 나타내었다. Fig. 2에는 인방보가 있으나 인방 보의 영향을 관찰하기 위해 인방보가 없는 경우의 부분 구조도 설계 제작하여 반복 횡가력 실험을 수행하였다.

\section{1 실물 실험체}

실물 실험체는 부산대에서 제작하고 횡가력 실험을 수 행하였다. 실험체는 실물크기(높이 : $6.5 \mathrm{~m}$ )로 계획되었으 나, 반력벽 높이 $(5 \mathrm{~m})$ 를 고려하여 $3: 5$ 으로 축소하여 실 험을 수행하였다. 실물크기 실험에 대한 자세한 내용은 


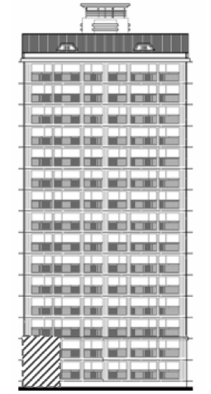

(a) Elevation

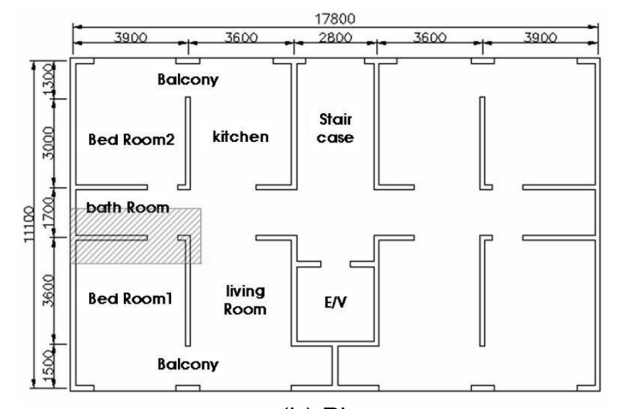

(b) Plan
Fig. 1 Elevation and plan of prototype RC wall building (unit: $\mathrm{mm}$ )

연차 연구보고서를 참고하였다.) 이 논문에서 $3: 5$ 실험 체를 편의상 실물 크기 실험체로 명명하고자 한다.

\section{2 축소모델 실험체}

사용예정인 부산대 지진실험센터 진동대의 용량 $(600 \mathrm{kN}$ -3 자유도 $-5 \times 5 \mathrm{~m}, 300 \mathrm{kN}-6$ 자유도- $4 \times 4 \mathrm{~m})$ 을 고려하여 축 소율 $(1: 7$ 및 $1: 10)$ 을 결정 하였으며, 개구부의 인방보 설치 유/무에 따라 실험체를 계획하여 총 4 개의 축소모 델 실험체(1:7 및 $1: 10$ 축소 인방보 유/무)를 제작하였 다. 이 논문에서는 지면의 제약으로 인해 $1: 7$ 축소모델 만 다루고자 한다.

\section{3 재료 특성}

\subsection{1 철근}

Fig. 2의 실물크기 철근(D16, D10)에 상응하여, 축소모 델 실험체 $(1: 7)$ 에서 $\mathrm{D} 2, \varnothing 1.4$ 의 모델철근이 사용되었다. 여기서 유의할 것은 $3: 5$ 실험체에서 이에 상응하는 철 근으로 사용된 D10과 D6이 Table 1과 Fig. 3에서 보듯 이, 실물크기 실험체의 철근 $\mathrm{D} 16$ 과 $\mathrm{D} 10$ 을 모사하는데 차이가 있다는 점이다. 그러나 이 논문에서는 $3: 5$ 실험 체에 사용된 철근 $\mathrm{D} 10$ 과 $\mathrm{D} 6$ 을 실물 실험체 철근으로 가 정하고 상사성을 평가하고자 한다. Fig. 2에서 $\mathrm{W} 1, \mathrm{~W} 2$, $\mathrm{W} 2$ '벽체의 수직근과 인방보의 주근에 해당하는 모델철 근 $\mathrm{D} 2$ 는 이형화 하였고, W3 벽체의 수직근과 모든 벽 체의 수평근, 슬래브의 철근, 인방보의 스터럽에 해당하 는 Ø1.4 모델철근은 이형화를 하지 않았다. 모델철근의 단면적이 정확하게 축소된 제품을 구하거나 제작하기 어 렵고, 그에 따라 응력을 맞출 수 없기 때문에 철근의 힘 에 축소율을 적용하여 항복력을 맞추었다. ${ }^{7.8)}$

\subsection{2 콘크리트}

실물 실험체의 콘크리트 굵은 골재 최대치수는 $13 \mathrm{~mm}$, 설계강도 $24 \mathrm{MPa}$ 로 타설하였다. 축소모델 실험체의 콘 크리트 ${ }^{9}$ 는 기 수행된 연구의 배합비 ${ }^{10}($ Table 2 )를 사용 하였으며, 굵은골재의 최대치수 $(25 \mathrm{~mm})$ 와 잔골재의 최대 치수 $(5 \mathrm{~mm})$ 는 축소율에 따라 선별하여 타설 하였다. 모

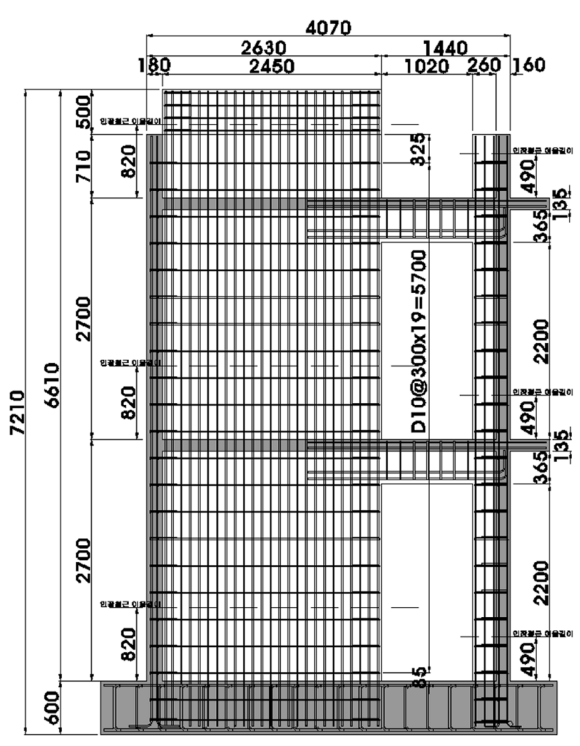

(a) Elevation

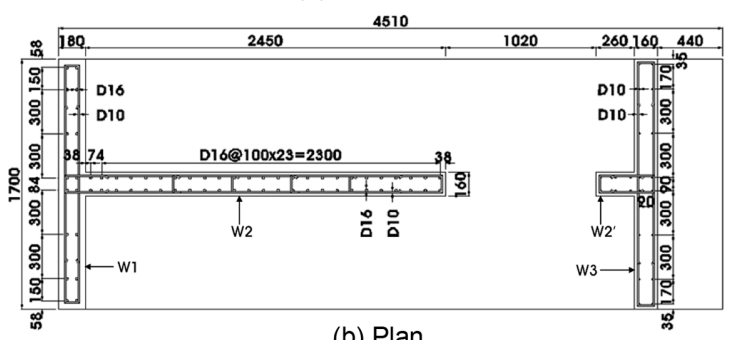

(b) Plan

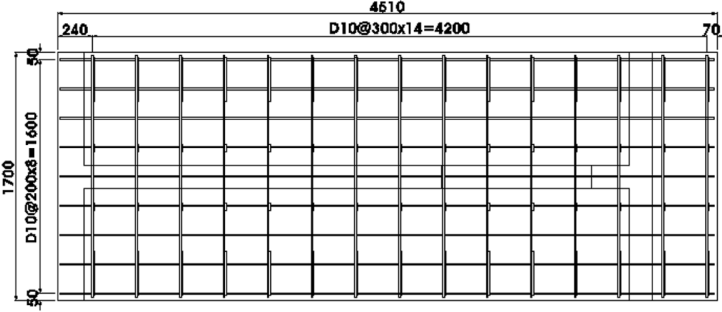

(c) Slab

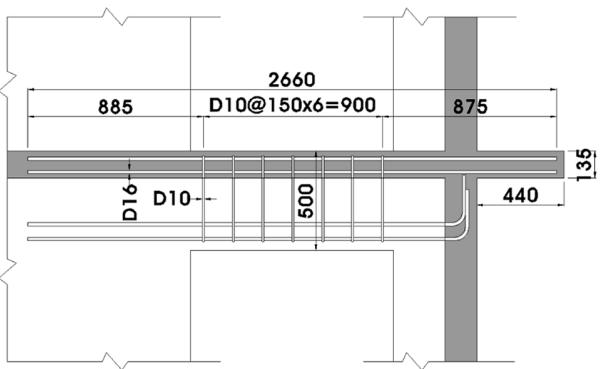

(d) Lintel beam

Fig. 2 Dimension details of full-scale subassemblage (unit: $\mathrm{mm}$ )

델 공시체 열처리된 모델철근( $\mathrm{D} 2, \varnothing 1.4)$ 을 실물 실험체 철근(3:5)의 강도기준으로 정규화 하여 Table 1 에서 비 교 하였다. 강도에서는 $\mathrm{D} 2$ 철근이 $3: 5$ 실험체의 $\mathrm{D} 10$ 철 근에 비하여 $35 \%$ 낮은 강도를 보였고, Ø1.4 철근은 $8 \%$ 의 낮은 강도 차이를 보였다(Fig. 3).

$(\varnothing 50 \times 100 \mathrm{~mm})$ 는 28 일 동안 실험체와 동일한 위치에 서 양생하였으며, 모델별 1 층, 2 층에 대해 별도의 배치 로 하여, 각 배치에 대해 3 개씩 제작하였다. 28 일 강도 가 Table 3에 나타나 있으며, 축소모델 실험체의 설계 강 도는 $24 \mathrm{MPa}$ 보다 크게 나타났다. 
Table 1 Similitude in prototype and model reinforcements

\begin{tabular}{|c|c|c|c|c|c|c|c|c|}
\hline \multirow[t]{2}{*}{ Specimens } & \multirow[t]{2}{*}{ Reinforcement } & \multirow{2}{*}{$\begin{array}{l}\text { Yielding force, } \\
\mathrm{F}_{\mathrm{y}}(\mathrm{kN})\end{array}$} & \multicolumn{2}{|c|}{$\begin{array}{c}\text { Normalized with respect } \\
\text { to } 3: 5 \text { specimen }\end{array}$} & \multirow{2}{*}{$\begin{array}{c}\text { Tensile } \\
\text { strength, } \\
\mathrm{F}_{\mathrm{u}}(\mathrm{kN})\end{array}$} & \multicolumn{2}{|c|}{$\begin{array}{l}\text { Normalized with respect } \\
\text { to } 3: 5 \text { specimen }\end{array}$} & \multirow{2}{*}{$\begin{array}{l}\text { Elongation } \\
\quad(\%)\end{array}$} \\
\hline & & & $\mathrm{F}_{\mathrm{y}}(\mathrm{kN})$ & $(2) /(1)(\%)$ & & $\mathrm{F}_{\mathrm{u}}(\mathrm{kN})$ & $(2) /(1)(\%)$ & \\
\hline \multirow{2}{*}{ Prototype (2) } & 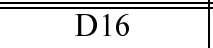 & 106 & 38.2 & 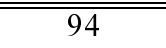 & 128 & 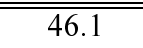 & 101 & 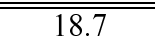 \\
\hline & D10 & 36.3 & 13.1 & 114 & 45.0 & 16.2 & 95 & 15.4 \\
\hline \multirow{2}{*}{$\begin{array}{c}3: 5 \text { specimen } \\
\text { (1) }\end{array}$} & D10 & 40.4 & 40.4 & 100 & 45.5 & 45.5 & 100 & 6.93 \\
\hline & D6 & 11.5 & 11.5 & 100 & 17.0 & 17.0 & 100 & 6.06 \\
\hline \multirow{2}{*}{$\begin{array}{c}1: 7 \text { model } \\
(2)\end{array}$} & D2 & 1.49 & 26.3 & 65 & 1.80 & 31.8 & 70 & 9.14 \\
\hline & $\varnothing 1.4$ & 0.603 & 10.6 & 92 & 1.18 & 20.8 & 122 & 11.2 \\
\hline
\end{tabular}
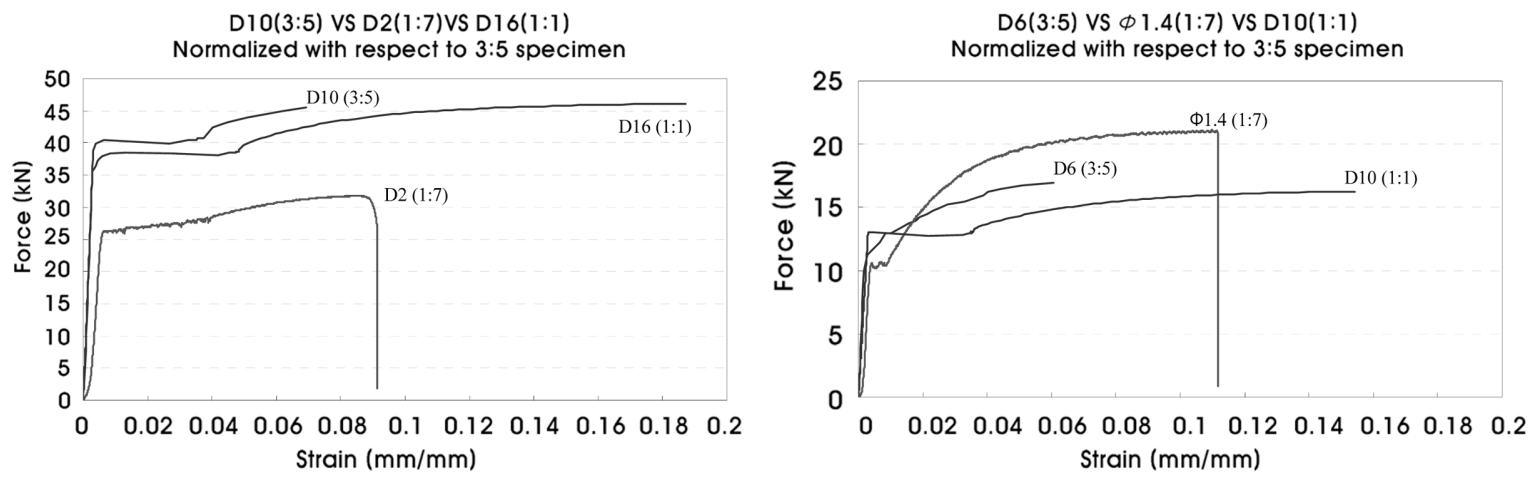

Fig. 3 Comparison of tensile test results (normalized with respect to $3: 5$ specimen)

Table 2 Mixing proportion of model concrete

\begin{tabular}{c|c|c|c|c|c}
\hline \multirow{2}{*}{ W/C (\%) } & \multirow{2}{*}{ S/a (\%) } & \multicolumn{4}{|c}{ Unit weight $\left(\mathrm{kg} / \mathrm{m}^{3}\right)$} \\
\cline { 3 - 6 } & & \multirow{2}{*}{$\mathrm{W}$} & $\mathrm{C}$ & \multicolumn{2}{|c}{ Aggregate } \\
\cline { 5 - 6 } & & & & Fine & Coarse \\
\hline \hline 63.7 & 47.0 & 354 & 557 & 653 & 736 \\
\hline
\end{tabular}

Table 3 Results of compression tests of concrete (unit: MPa)

\begin{tabular}{c|c|c}
\hline Specimen & Story & $f_{c k}$ \\
\hline \hline \multirow{2}{*}{$3: 5$ specimen } & First & 23.3 \\
\cline { 2 - 3 } & Second & 23.5 \\
\hline \multirow{2}{*}{$1: 7$ model } & First & 29.0 \\
\cline { 2 - 3 } & Second & 25.5 \\
\hline
\end{tabular}

\section{4 시공 과정}

실물 실험체는 부산대학교 구조 실험동 내부에서 3주 동안 제작하였다. 축소모델 실험체의 기초는 실물 콘크 리트, 1 층·2층·3층은 모델 콘크리트를 이용하여 총 4번의 콘크리트를 타설하였으며, 각 층의 벽, 슬래브, 인방보의 모델 철근을 사전 조립하여 실험체에 결합하였다(Fig. 4). 총 4 개의 모델을 제작하는데 한 달의 기간이 소요되었 으며, 한 달의 기간 중 $80 \%$ 이상의 작업 시간을 철근 조 립 및 조립된 철근을 실험체에 결합하는데 소비하였다.

\section{5 실험 장치 및 데이터 취득}

\subsection{1 실험 장치}

실물크기 부분구조의 실험은 Fig. 5와 같이 반력벽에 액 츄에이터를 지지하고 실험체에 횡력을 가하도록 하였다.

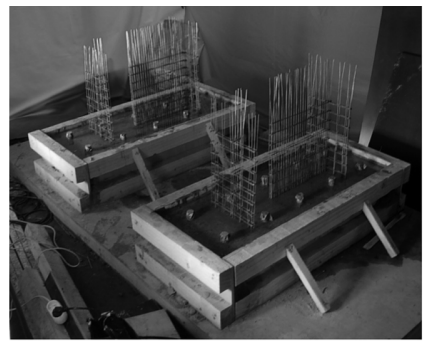

(a) Reinforcement

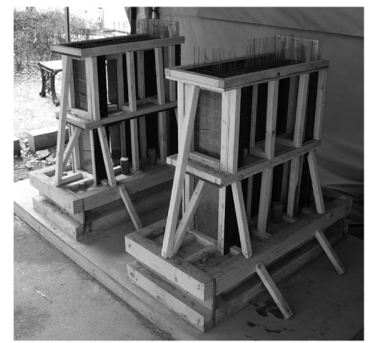

(b) Formwork
Fig. 4 Construction of $1: 7$ model

축소모델 실험체의 실험세팅은 실물 실험체와 동일한 형 태로 하였다. $3: 5$ 실험체와 $1: 7$ 축소모델에서 자체 무게 에 대한 상사성을 유지하기 위해 Table 4와 같이 계산된 부 가질량(added weight)을 가력부 상단에 추가로 설치하였다.

Fig. 6과 같이 실험도중 실험체가 틀어지는 것을 방지하 기 위해 실험체 측면에 가이드 레일을 설치하였다. 액츄에 이터는 스트롱 프레임에 고정시키고 액츄에이터 앞부분에 두 개의 힌지를 설치하여 횡력만을 전달할 수 있게 하였다.

\subsection{2데이터 취득}

실험체의 계측은 Fig. 7(b), (c) 및 (d)와 같이 액츄에이 터의 로드셀(1개), 층변위(4개), 전단변위(10개), 축변위 (13개), 들뜸변위(9개)를 포함하여 총 37개의 데이터를 취 득할 수 있도록 계측하였고, 인방보의 전단변위 등 협소 한 부분의 계측을 위해 포텐쇼메타를 사용하였다.

\subsection{3 가력부 변위 프로토콜}

Fig. 7(c)에 가력지점과 횡변위 계측위치가 $3: 5$ 실험체 


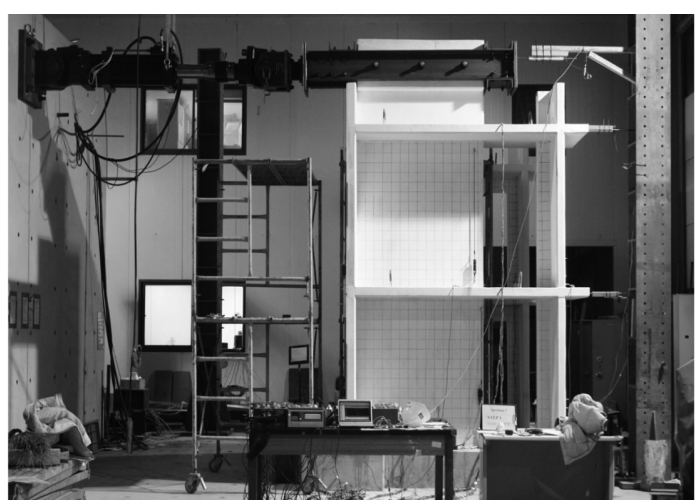

Fig. 5 Experimental setup ( $3: 5$ specimen)

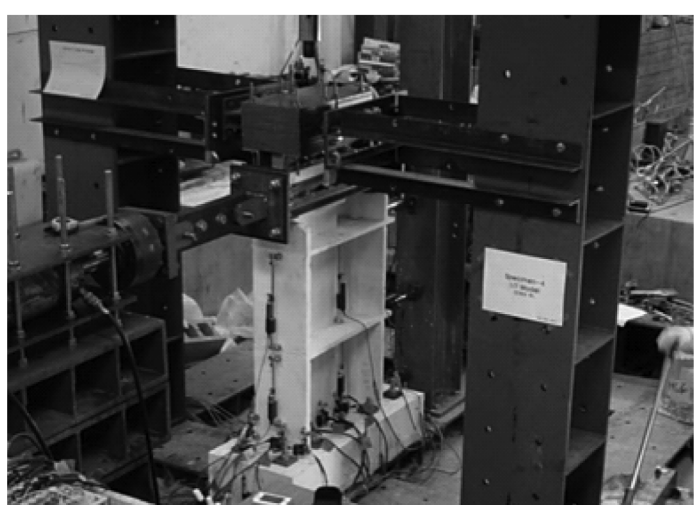

Fig. 6 Experimental setup (1:7 model)
Table 4 Added weight

(unit: $\mathrm{kN}$ )

\begin{tabular}{c|c|c|c|c}
\hline Specimens & $\begin{array}{c}\text { Weight of } \\
\text { specimens }\end{array}$ & $\begin{array}{c}\text { Weight by } \\
\text { similitude }\end{array}$ & $\begin{array}{c}\text { Required } \\
\text { added weight }\end{array}$ & $\begin{array}{c}\text { Added } \\
\text { weight }\end{array}$ \\
\hline \hline $3: 5$ specimen & 42.9 & 42.9 & - & - \\
\hline $1: 7$ model & 0.199 & 1.19 & 0.994 & 1.03 \\
\hline
\end{tabular}

에(괄호안은 $1: 7$ 모델)대해 표시되어있다. 가력변위 프로 토콜은 Fig. 7(a)와 같이 의도하였으나, 실제 실행된 가 력변위 이력은 Fig. 8(a)와 같이 $3: 5$ 실험체인 경우 (-) 방향에서 상당히 부족한 변위를 나타내고 있음을 알 수 있다. 가력부는 실제 사용 가력기에 맞게 설계하였기 때 문에 1:7축소모델 실험체의 경우 가력부위의 크기가 상 대적으로 커지게 되었다. 이로 인해 기초부터 가력지점 까지의 높이(3/5실험체 : $1 / 7$ 축소모델) 비율이 상사성 비 율인 4.2:1을 정확히 만족하지 못하고 있다.

Fig. 8의 실제 가력변위 이력이 의도된 변위이력인 Fig. 7(a)를 정확히 만족시키지 못했지만 이 논문에서는 추후 각 단계별 변위 수준을 의도된, 또는 명목 변위수준의 표 현인 $0.5 \%, 0.75 \%, 1 \%, 1.5 \%$ 및 $2 \%$ 로 표시하기로 한다.

\section{3. 실험 결과 및 상사성 분석}

\section{1 횡가력 이력과 횡변위 분포}

2.5.3에서 언급하였듯이, 상사성에 비추어 가력지점이 실

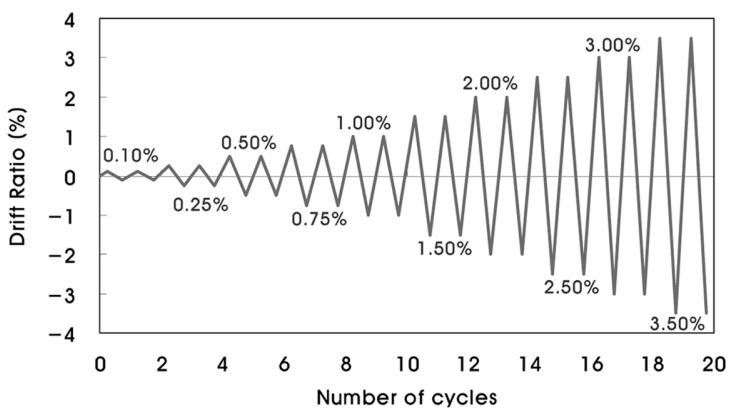

(a) Loading history (unit: \%)

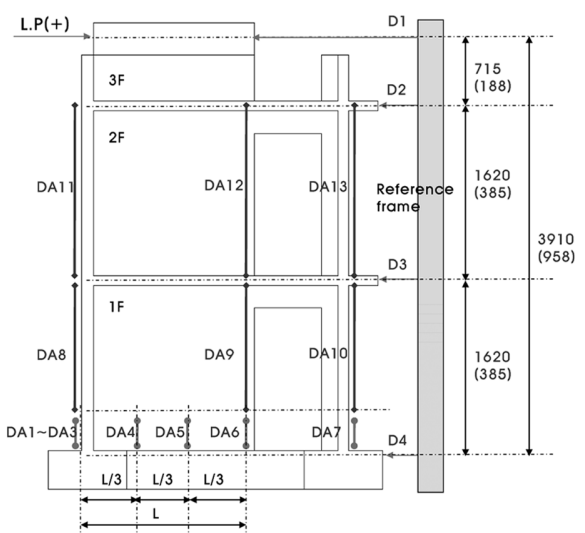

(c) Lateral story displacement, axial and rotational deformation

Fig. 7 Loading history and Instrumentation

808 한국콘크리트학회 논문집 제22권 제6호 (2010)

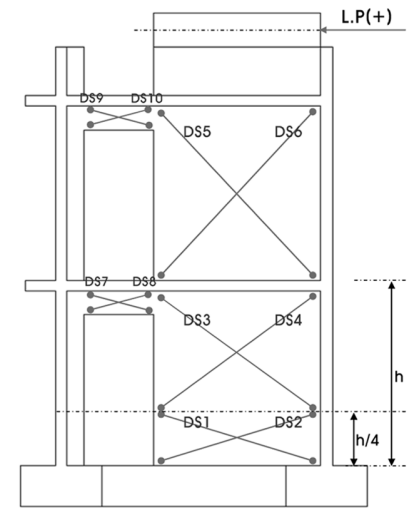

(b) Shear deformation

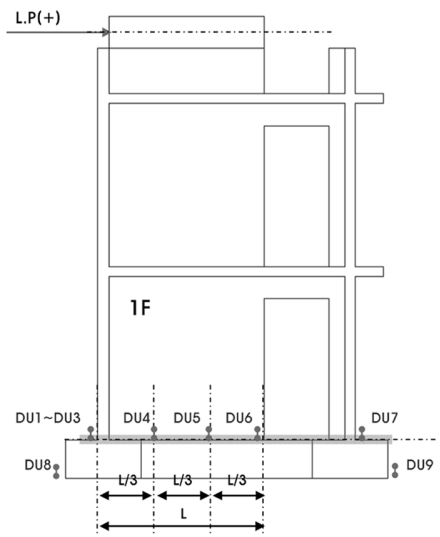

(d) Up-lift deformation 


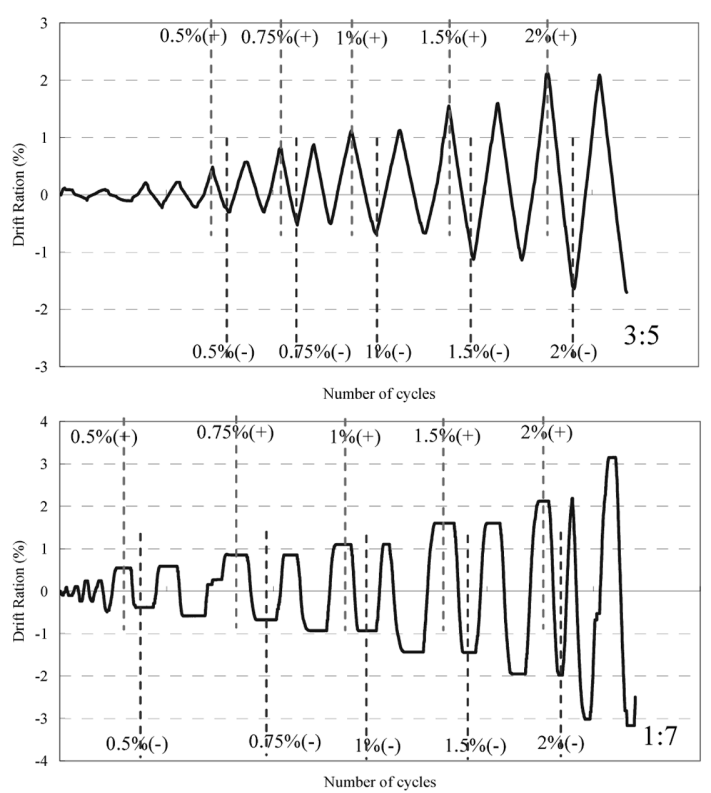

(a) With lintel beam
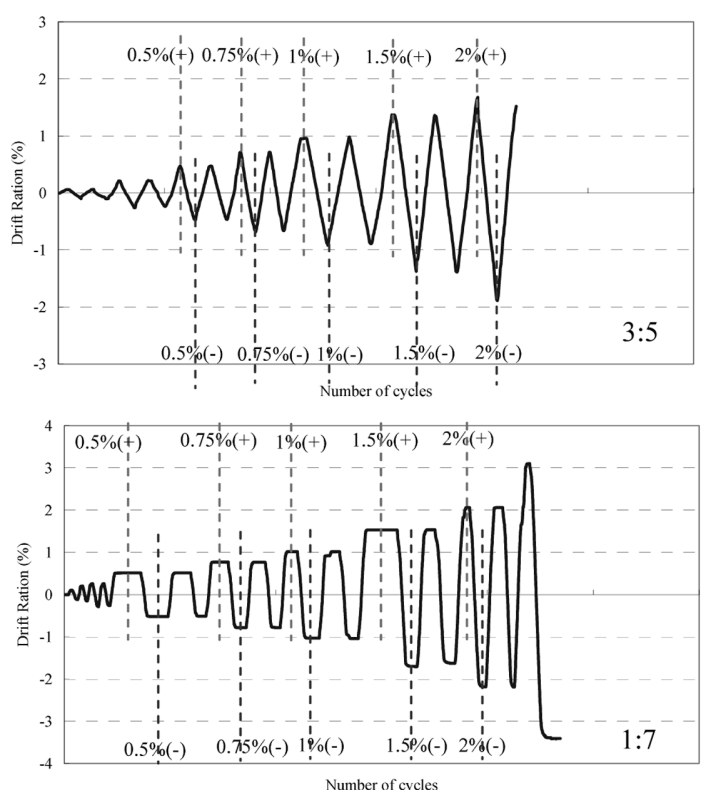

(b) Without lintel beam

Fig. 8 Actual drift history at loading point (LP) (vertical dotted lines mean the times of data presented hereafter)

물 실험체와 축소모델 실험체에서 상응한 지점이 아니다. 그리고 3 층 바닥위의 가력부와 3 층 벽체의 변형은 관심부 분이 아니기 때문에 Fig. 9 에서 이 부분을 제외하고 2 층과 3 층 바닥의 횡변위를 변위 단계별로 나타내었다. Fig. 9에 서 정방향과 부방향 변위의 측정시점은 Fig. 8에 나타나 있다. 이후 모든 거동의 상사성 비교에서도 동일한 시점 의 데이터가 사용된다. 인방보의 유무에 상관없이 횡변위 의 수직분포가 대체로 역삼각형을 이룸을 알 수 있다. 기 울기에 있어서 2 층 부분에서 실물 실험체의 기울기가 축 소모델 실험체에 비해 약간 더 가파른 것을 볼 수 있다.

\section{2 전체거동의 상사성}

\subsection{1 강도}

축소모델 실험체의 하중-변위 곡선을 상사성 관계에 부 합되게 실물 실험체에 맞춘 곡선이 Fig. 10에서 비교하 여 나타내었다. 축소모델 실험체는 인방보 유/무와 관계 없이 최대강도가 대칭적인 값을 보여주며, 정-부방향에 서 29 39\%정도 작은 강도를 나타내었다. 이는 Table 1 에 나타난 벽체의 모델 주 철근의 강도에서 원인을 찾 을 수 있었다. 모델철근이 실물철근의 항복강도보다 $35 \%$ 정도 작다는 점을 감안한다면 축소모델의 상사성이 잘 맞다고 할 수 있다.

\subsection{2 강성}

인방보가 있는 경우 축소모델 실험체의 초기강성이 실 물 실험체에 비해 $45 \%$, 인방보가 없는 경우는 $22 \%$ 작 게 나타났다(Fig. 11).

\subsection{3연성}

참고문헌 ${ }^{11}$ 에 따라 항복변위는 최대강도의 $75 \%$ 에 해

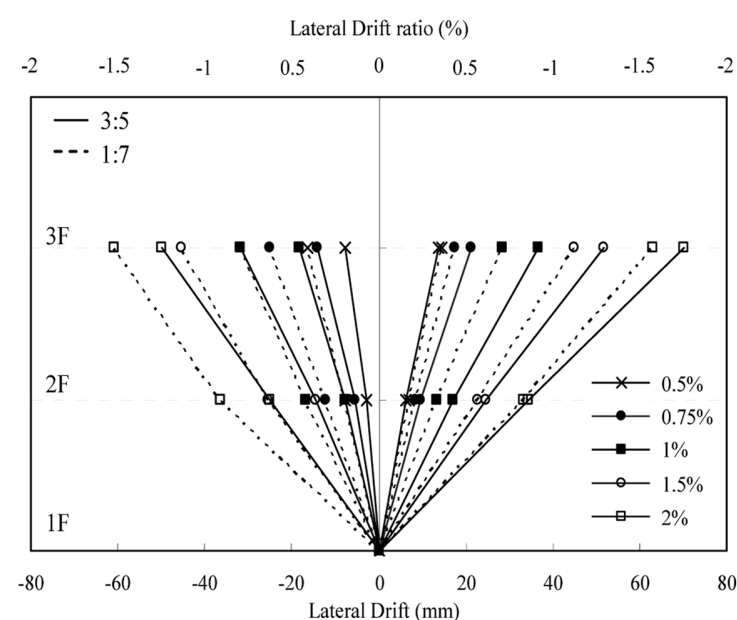

(a) With lintel beam

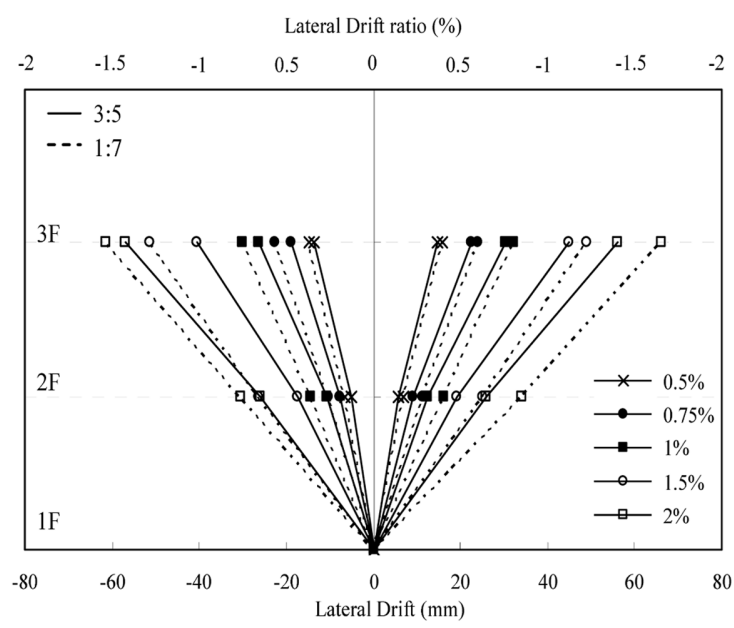

(b) Without lintel beam

Fig. 9 Drift envelope

당되는 하중이 처음 도달되는 변위점과 원점을 연결한 선이 최대 강도점을 수평으로 지나는 선과의 만나는 점 


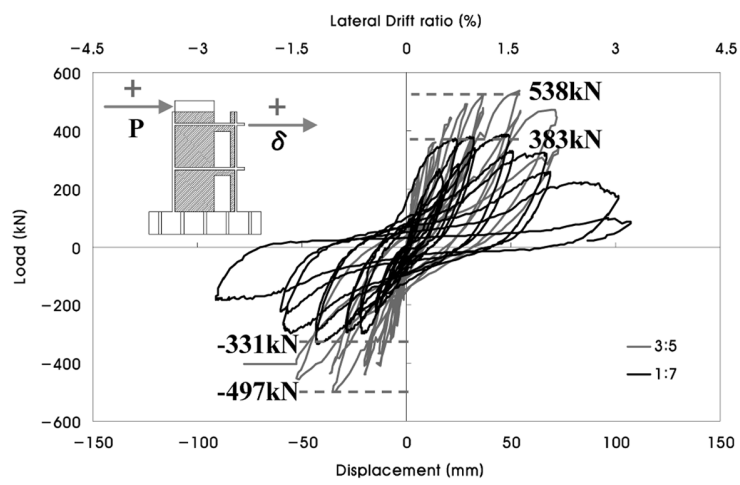

(a) With lintel beam

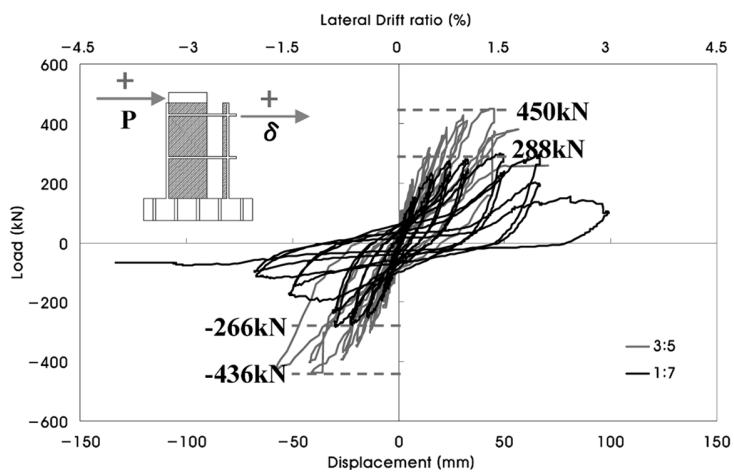

(b) Without lintel beam

Fig. 10 Comparison with specimens Load-displacements (Normalized with respect to $3: 5$ specimen)
을 항복변위로 정의하였고, 최대변위는 하중이 최대강도 보다 $15 \%$ 이상 저감될 때의 변위로 정의하였다. 인방보 가 있는 실물 실험체의 양의 방향 연성비는 2.75 , 축소 모델 실험체의 연성비는 2.57 로 $7 \%$ 작게 나타났다. 인방 보가 없는 경우 실물 실험체의 연성비는 2.57 , 축소모델 실험체는 3.46 로 $26 \%$ 크게 나타났다(Fig. 11, Table 5).

\subsection{4 파기모드}

가력방향으로 평행한 웨브 벽체, 슬래브, 인방보의 최 종 파괴형태를 Fig. 12와 Table 6에 나타내었으며, 개구 부 주위로 인방보의 콘크리트 박리, 웨브 벽체의 압축파 괴 및 들뜸, 인방보의 휨 균열 형상을 관찰할 수 있다.

실물 실험체와 축소모델 실험체간에 유사한 파괴형태로 는 인방보를 가진 실험체는 인방보의 전단균열 및 피복 탈락, 인방보를 가지지 않는 실험체는 슬래브가 휨 균열 이 비교적 크게 발생하였다. 모든 실험체에서 웨브 벽체 균열은 개구부 옆에서의 수평의 휨 균열로 시작하였고, 벽 체의 중앙부에서는 대각선의 전단균열이 발생하였다. 최 종적으로 웨브 벽체의 개구부 옆 하단 주근이 좌굴 후 절 단이 되는 경향을 보였다. 실물크기 실험체에서의 최대 강 도 시 파괴는 웨브 벽체의 우측 최하단의 콘크리트 압축 파괴가 주요 파괴모드였으나, 축소모델 실험체에서는 압

Table 5 Comparison of ductility ratio

\begin{tabular}{|c|c|c|c|c|c|c|c|}
\hline & \multirow{2}{*}{ Specimens } & \multicolumn{2}{|c|}{ Push $(+)$} & \multirow{2}{*}{$\mu_{\Delta}$} & \multicolumn{2}{|c|}{ Pull (-) } & \multirow{2}{*}{$\mu_{\Delta}$} \\
\hline & & $\Delta_{y}$ & $\Delta_{u}$ & & $\Delta y$ & $\Delta_{u}$ & \\
\hline \multirow{2}{*}{$3: 5$} & Without lintel beam & 22 & 56.5 & 2.57 & -23 & -57.8 & 2.51 \\
\hline & With lintel beam & 26 & 71.5 & 2.75 & -22 & -52.5 & 2.37 \\
\hline \multirow{2}{*}{$1: 7$} & Without lintel beam & 19 & 65.7 & 3.46 & -21 & -50.0 & 2.51 \\
\hline & With lintel beam & 26 & 66.9 & 2.57 & -19 & -55.2 & 2.91 \\
\hline
\end{tabular}

Note) $\Delta_{\mathrm{y}}$ : yield displacement, $\Delta_{\mathrm{u}}:$ ultimate displacement, $\mu_{\Delta}$ : ductility ratio
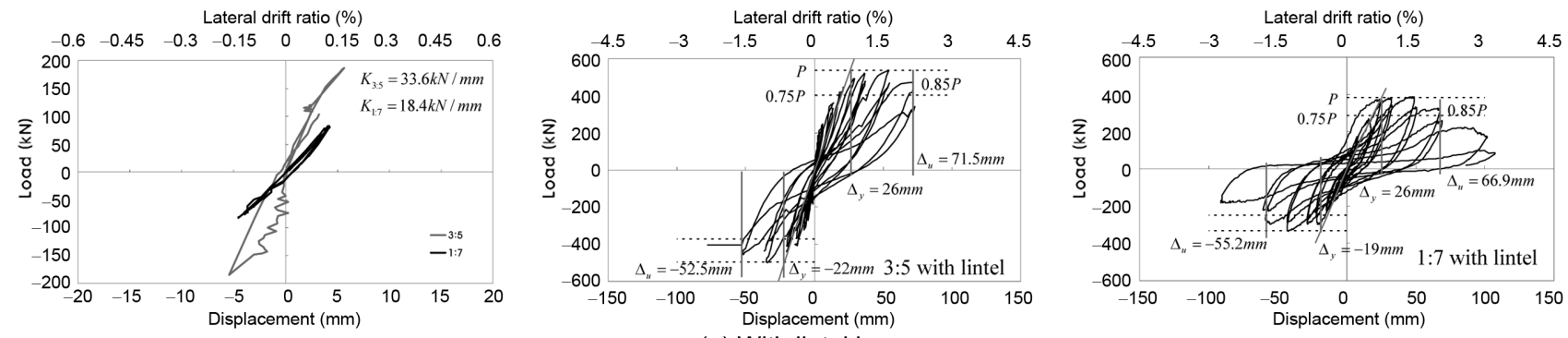

(a) With lintel beam

Lateral drift ratio (\%)
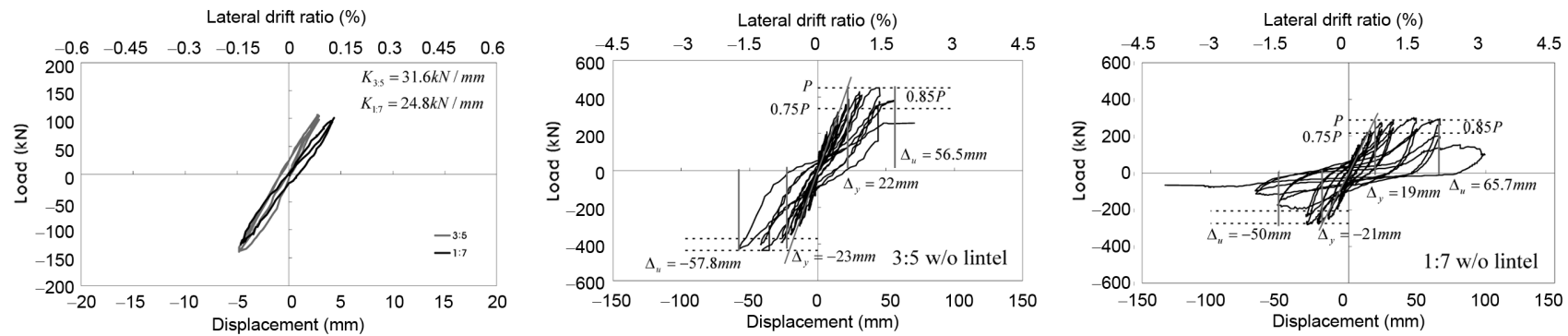

(b) Without lintel beam

Fig. 11 Comparison with specimens stiffness and ductility (Normalized with respect to $3: 5$ specimen) 
2 story

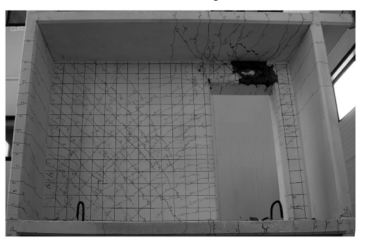

1 story

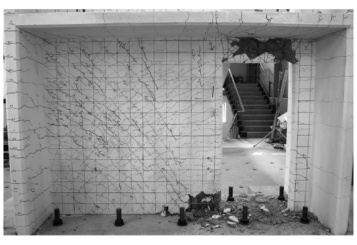

3:5 specimen

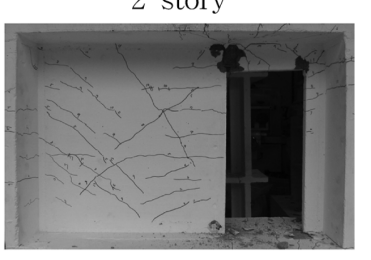

1 story

1:7 model

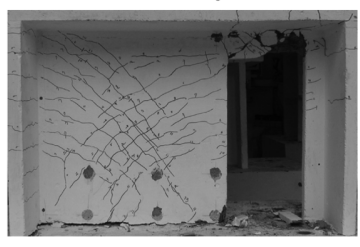

(a) With lintel beam
2 story

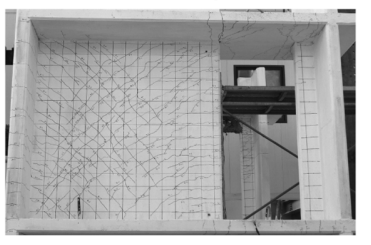

1 story

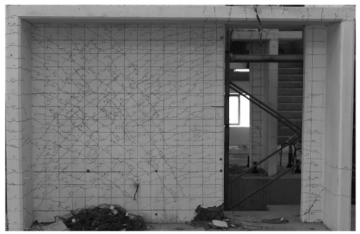

3:5 specimen

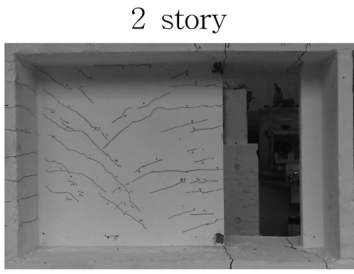

1 story

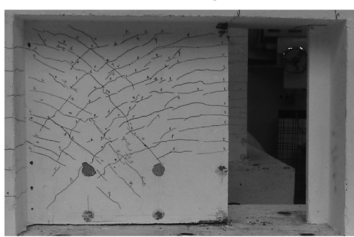

1:7 model (b) Without lintel beam

Fig. 12 Final crack and damage distributions (W2)

축파괴 영역이 매우 축소되면서 기초와의 들뜸이 밑면 전 체에 걸쳐 두드러진 경향을 나타내고 있다. 상이한 파괴 형태로는 실물 실험체 웨브 벽체는 층고의 $0.1 \%$ 부터 균 열이 시작된 반면 축소모델 실험체는 층고의 $0.5 \%$ 부터 균
열이 시작되었으며, 축소모델 실험체가 실물 실험체에 비 해 대체적으로 벽체의 균열 폭이 크고 균열수가 적었다.

\section{3 인방보의 영향}

\subsection{1 강도}

실물 실험체에서 인방보가 있는 경우 최대강도는 정방 향일 때 $16 \%$, 부방향일 때 $12 \%$ 인방보가 없는 경우 보 다 크게 나타났다. 축소모델 실험체에서도 인방보가 있 는 경우 정방향일 때 $25 \%$, 부방향일 때 $24 \%$ 크게 나타 났다(Fig. 13).

\subsection{2 강성}

실물 실험체에서 인방보가 있는 경우 초기강성이 인방 보가 없는 경우 보다 $6 \%$ 크게 나타났다. 그러나 축소모 델 실험체에서의 초기강성은 인방보가 있는 경우 인방보 가 없는 경우 보다 $36 \%$ 작게 나타났다(Fig. 13).

\subsection{3 연성}

인방보가 있는 실물 실험체의 연성비는 2.75 , 인방보가 없는 실물 실험체는 2.57 로 거의 비슷하게 나타났다. 인 방보가 있는 경우 축소모델 실험체의 연성비는 2.57 , 인 방보가 없는 경우의 3.46 보다 $35 \%$ 작게 나타났다(Table 5).

\section{4 국부거동의 상사성}

국부변위는 벽체의 휨 회전각(인방보 유/무), 벽체 및 인방보의 전단변형, 벽체 $1 / 4$ 하부의 휨 수직변형 분포 와, 밑면의 들뜸 분포를 실물 실험체와 축소모델 실험체 에 대해 비교하였다. ${ }^{12,13)}$

Fig. 14 는 1 층 상부 $3 / 4$ 영역의 양단 휨 수직변형과 그

Table 6 Development of cracks and damage

\begin{tabular}{|c|c|c|c|c|c|}
\hline \multirow{2}{*}{\multicolumn{2}{|c|}{ Step }} & \multicolumn{2}{|c|}{ With lintel beam } & \multicolumn{2}{|c|}{ Without lintel beam } \\
\hline & & $3: 5$ specimen & $1: 7$ model & $3: 5$ specimen & $1: 7$ model \\
\hline \multirow{3}{*}{$0.1 \%$} & W1 & $\begin{array}{l}\text { Initiation of flexural crack } \\
\text { in } 1 \text { st story wall }\end{array}$ & \multirow{3}{*}{ No crack } & $\begin{array}{l}\text { Initiation of flexural crack } \\
\text { in } 1 \text { st story wall }\end{array}$ & \multirow{3}{*}{ No crack } \\
\hline & W2 & $\begin{array}{l}\text { Initiation of flexural crack in } \\
\text { slab around opening and } \\
\text { shear crack in 1st story lintel }\end{array}$ & & $\begin{array}{l}\text { Initiation of flexural crack } \\
\text { in slab around opening }\end{array}$ & \\
\hline & W3 & No crack & & No crack & \\
\hline \multirow{3}{*}{$0.25 \%$} & W1 & Increase of crack width & \multirow{3}{*}{ No crack } & Increase of crack width & \multirow{3}{*}{ No crack } \\
\hline & W2 & $\begin{array}{l}\text { Initiation of shear crack in } \\
1 \text { st, 2nd story wall and shear } \\
\text { crack in 2nd story lintel }\end{array}$ & & $\begin{array}{l}\text { Initiation of shear crack in } \\
1 \text { st, } 2 \text { nd story wall }\end{array}$ & \\
\hline & W3 & Initiation of flexural crack & & Initiation of flexural crack & \\
\hline \multirow{3}{*}{$0.5 \%$} & W1 & Increase of crack width & $\begin{array}{l}\text { Initiation of up-lift in } 1 \mathrm{st} \\
\text { story wall }\end{array}$ & \multirow{3}{*}{ Increase of crack width } & $\begin{array}{l}\text { Initiation of up-lift in } 1 \mathrm{st} \\
\text { story wall }\end{array}$ \\
\hline & W2 & $\begin{array}{l}\text { Initiation of concrete crush- } \\
\text { ing at the bottom of wall } \\
\text { (opening) }\end{array}$ & $\begin{array}{l}\text { Initiation of flexural crack } \\
\text { in slab around opening and } \\
\text { shear crack in } 1 \text { st, } 2 \text { nd story } \\
\text { lintel }\end{array}$ & & $\begin{array}{l}\text { Initiation of flexural crack } \\
\text { in slab around opening and } \\
\text { shear crack in } 1 \text { st story lin- } \\
\text { tel, Initiation of up-lift in } 1 \mathrm{st} \\
\text { story wall }\end{array}$ \\
\hline & W3 & Initiation of vertical crack & $\begin{array}{l}\text { Initiation of up-lift and shear } \\
\text { crack in } 1 \text { st story wall }\end{array}$ & & No crack \\
\hline
\end{tabular}


Table 6 Development of cracks and damage (Continued)

\begin{tabular}{|c|c|c|c|c|c|}
\hline \multirow{2}{*}{\multicolumn{2}{|c|}{ Step }} & \multicolumn{2}{|c|}{ With lintel beam } & \multicolumn{2}{|c|}{ Without lintel beam } \\
\hline & & $3: 5$ specimen & \multirow{2}{*}{$\begin{array}{l}1: 7 \text { model } \\
\text { Increase of up-lift at the bot- } \\
\text { tom of wall(opening, } 2 \mathrm{~mm} \text { ) }\end{array}$} & \multirow{2}{*}{$\begin{array}{c}3: 5 \text { specimen } \\
\text { Initiation of vertical crack }\end{array}$} & $1: 7$ model \\
\hline \multirow{3}{*}{$0.75 \%$} & W1 & $\begin{array}{l}\text { Initiation of up-lift at bot- } \\
\text { tom }\end{array}$ & & & $\begin{array}{l}\text { Increase of up-lift in wall } \\
(1 \mathrm{~mm})\end{array}$ \\
\hline & W2 & $\begin{array}{l}\text { Increase of concrete crush- } \\
\text { ing at the bottom of wall } \\
\text { (opening) }\end{array}$ & $\begin{array}{l}\text { Initiation of shear crack in } \\
1 \text { st, } 2 \text { nd story wall }\end{array}$ & $\begin{array}{l}\text { Initiation of concrete crush- } \\
\text { ing at the bottom of wall } \\
\text { (opening) }\end{array}$ & $\begin{array}{l}\text { Spalling of concrete at the } \\
\text { bottom of wall(opening), } \\
\text { Increase of up-lift in } 1 \mathrm{st} \\
\text { story wall }(1 \mathrm{~mm})\end{array}$ \\
\hline & W3 & Increase of crack width & $\begin{array}{l}\text { Initiation of flexural crack } \\
\text { in 2nd story wall }\end{array}$ & Increase of crack width & No crack \\
\hline \multirow{3}{*}{$1.0 \%$} & W1 & Increase of crack width & $\begin{array}{l}\text { Increase of up-lift in 1st } \\
\text { story wall }(2 \mathrm{~mm})\end{array}$ & Increase of crack width & Increase of crack width \\
\hline & W2 & $\begin{array}{l}\text { Spalling of concrete at the } \\
\text { bottom of wall(opening) }\end{array}$ & $\begin{array}{l}\text { Increase of up-lift at the bot- } \\
\text { tom of wall(opening) Spal- } \\
\text { ling of concrete in the 1st } \\
\text { story lintel }\end{array}$ & $\begin{array}{l}\text { Increase of concrete crush- } \\
\text { ing at the bottom of wall } \\
\text { (opening) }\end{array}$ & $\begin{array}{l}\text { Buckling of long.bar at bot- } \\
\text { tom near opening }\end{array}$ \\
\hline & W3 & Increase of crack width & Increase of crack width & Increase of crack width & No crack \\
\hline \multirow{3}{*}{$1.5 \%$} & W1 & Increase of crack width & \multirow{3}{*}{ Increase of crack width } & Increase of crack width & $\begin{array}{l}\text { Fracture of long.bar at bot- } \\
\text { tom }\end{array}$ \\
\hline & W2 & $\begin{array}{l}\text { Buckling of long.bar at bot- } \\
\text { tom near opening, Spalling of } \\
\text { concrete in 1st, 2nd story } \\
\text { lintel }\end{array}$ & & $\begin{array}{l}\text { Spalling of concrete at the } \\
\text { bottom of wall(opening) }\end{array}$ & $\begin{array}{l}\text { Fracture of long.bar at bot- } \\
\text { tom near opening, Increase } \\
\text { of up-lift in } 1 \mathrm{st} \text { story wall } \\
(10 \mathrm{~mm})\end{array}$ \\
\hline & W3 & Increase of crack width & & Increase of crack width & No crack \\
\hline \multirow{3}{*}{$2.0 \%$} & W1 & Increase of up-lift at bottom & $\begin{array}{l}\text { Increase of up-lift in 1st } \\
\text { story wall }(5 \mathrm{~mm})\end{array}$ & Up-lift failure at bottom & \multirow{3}{*}{-} \\
\hline & W2 & $\begin{array}{l}\text { Fracture of long.bar at bot- } \\
\text { tom near opening }\end{array}$ & $\begin{array}{l}\text { Spalling of concrete in 2nd } \\
\text { story lintel and at the bot- } \\
\text { tom of wall(opening) }\end{array}$ & \multirow[t]{2}{*}{ - } & \\
\hline & W3 & Increase of crack width & Increase of crack width & & \\
\hline \multirow{3}{*}{$2.5 \%$} & W1 & \multirow{3}{*}{ - } & $\begin{array}{l}\text { Increase of up-lift in 1st } \\
\text { story wall }(10 \mathrm{~mm})\end{array}$ & \multirow{3}{*}{-} & \multirow{3}{*}{-} \\
\hline & W2 & & $\begin{array}{l}\text { Fracture of long bar at bot- } \\
\text { tom near opening }\end{array}$ & & \\
\hline & W3 & & - & & \\
\hline
\end{tabular}
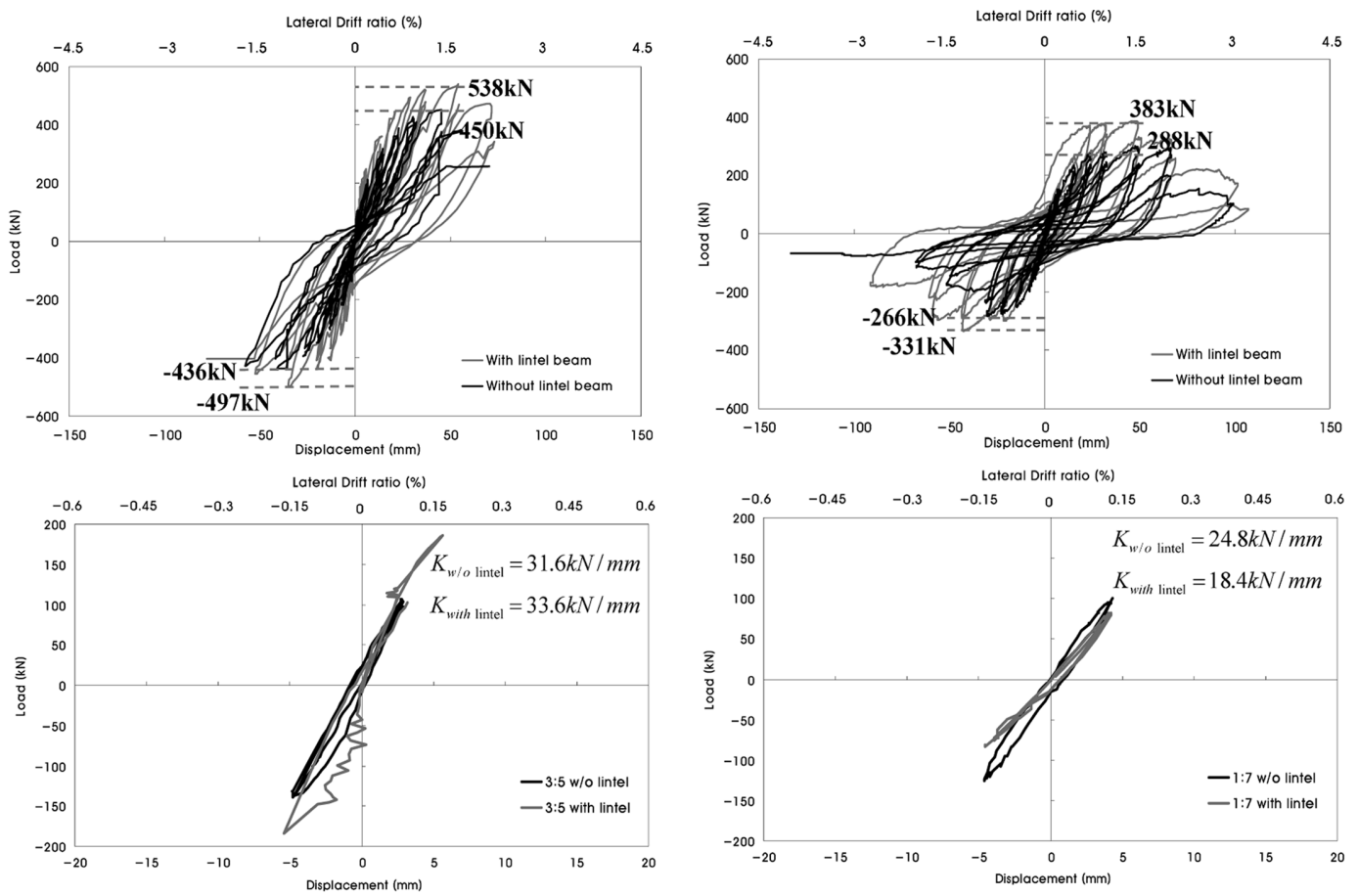

(a) $3: 5$ specimen

(b) $1: 7$ model

Fig. 13 Comparison of behavior with and without lintel (normalized with respect to $3: 5$ model) 
에 따른 휨 회전각을 가력 사이클에 따라 나타내었다. 가력 시 DA8과 DA9(Fig. 7 참조)는 서로 반대방향으로 움직이는 것을 확인할 수 있으며, 축소모델 실험체의 회 전각이 실물 실험체 보다 크게 나타났다. 이러한 방식으
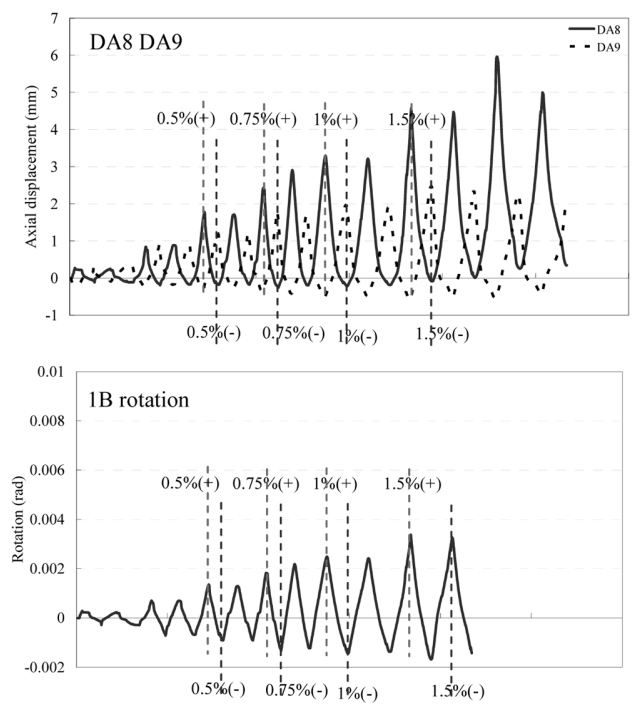

(a) Wall with lintel 3:5
로 얻어진 층별 휨 회전각 분포를 1 층 밑면의 들뜸에 의 한 회전각(1U)을 포함하여 Fig. 17에 나타내었다. 실물 실험체의 경우 회전각의 분포는 들뜸에 의한 값(1U)이 제일 크게 나타났고, 2층보다 1층 상부(1B) 분포값이 크
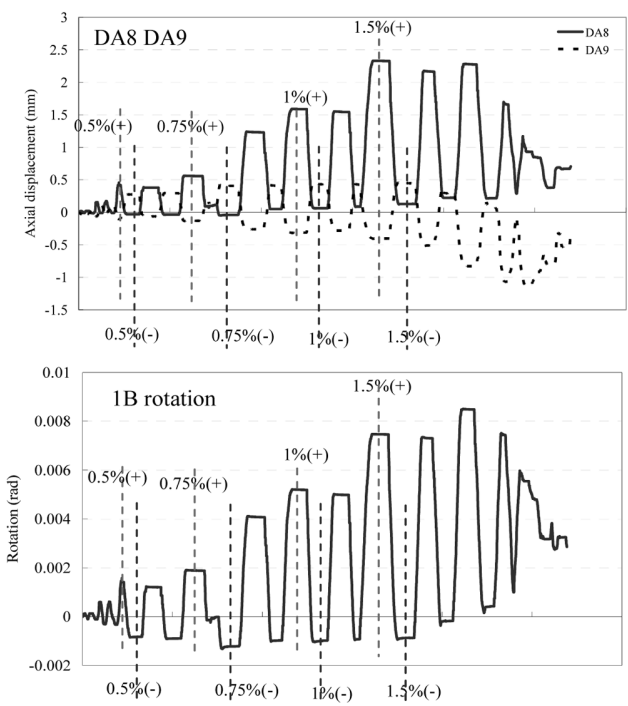

(b) Wall with lintel 1:7

Fig. 14 Flexural rotation in the upper $3 / 4$ region of 1 st story
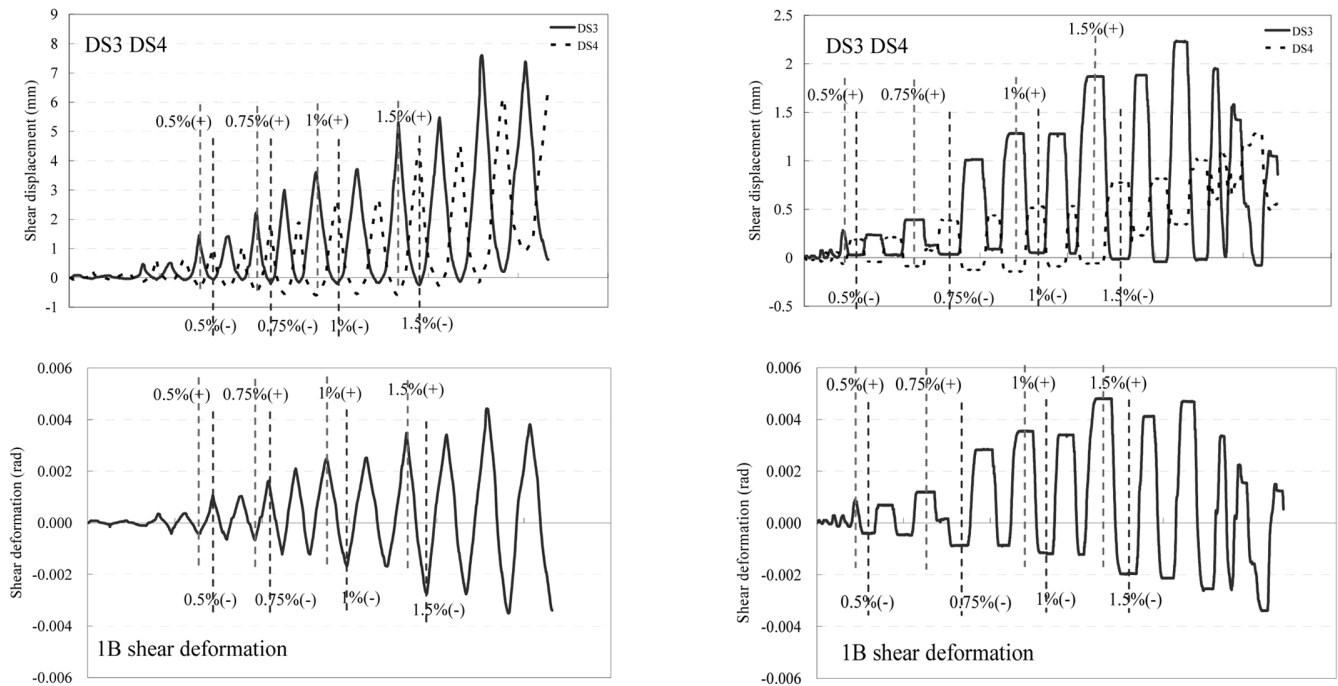

(a) Wall with lintel 3:5

(b) Wall with lintel 1:7

Fig. 15 Shear deformation in the upper $3 / 4$ region of 1 st story

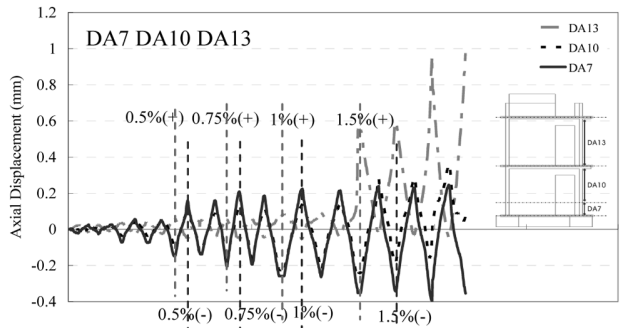

(a) Wall without lintel 3:5

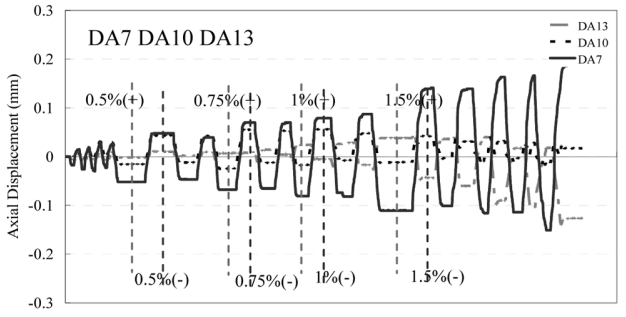

(b) Wall without lintel 1:7

Fig. 16 Elongation along the height in W3 


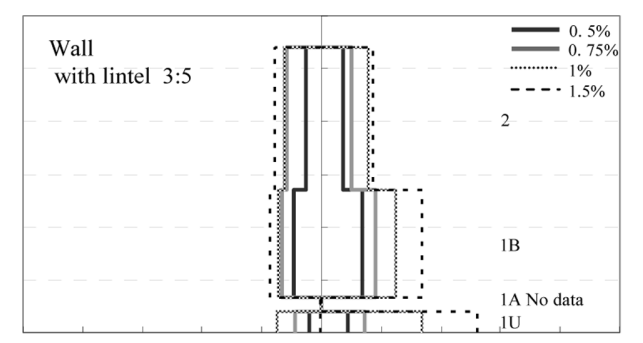

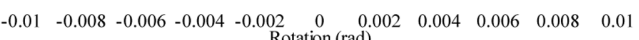

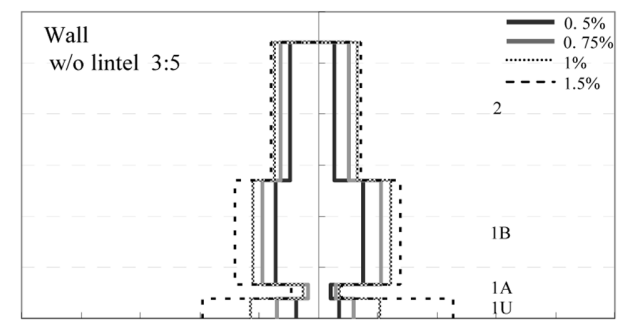

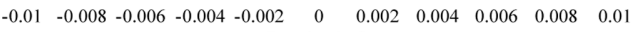
Rotation (rad)

(a) $3: 5$ specimen

Fig. 17 Flexural rotations

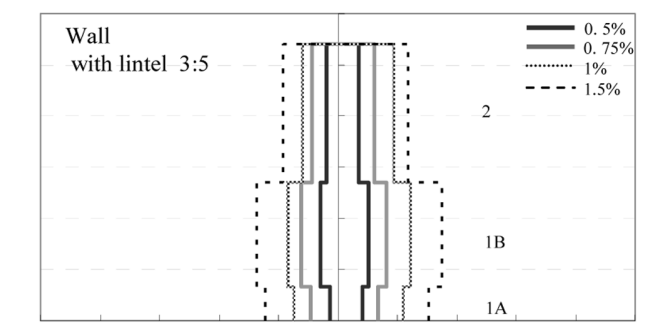

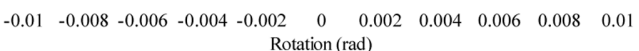

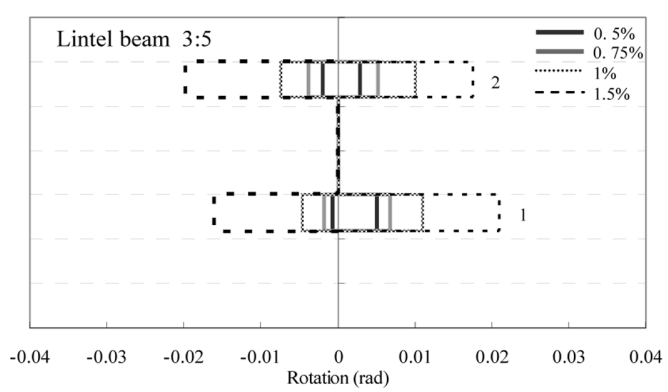

(a) $3: 5$ specimen

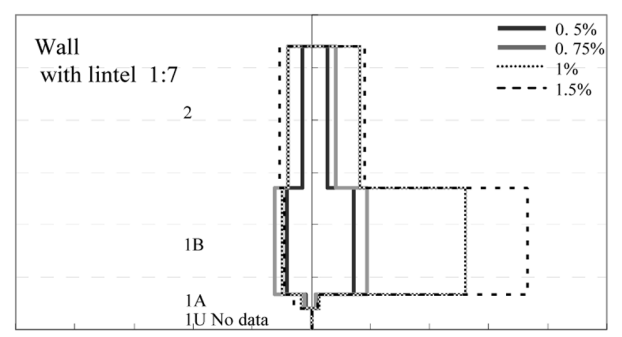

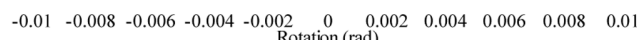

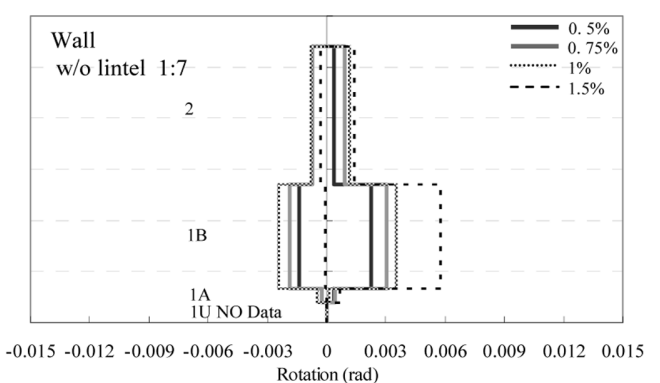

(b) $1: 7$ model
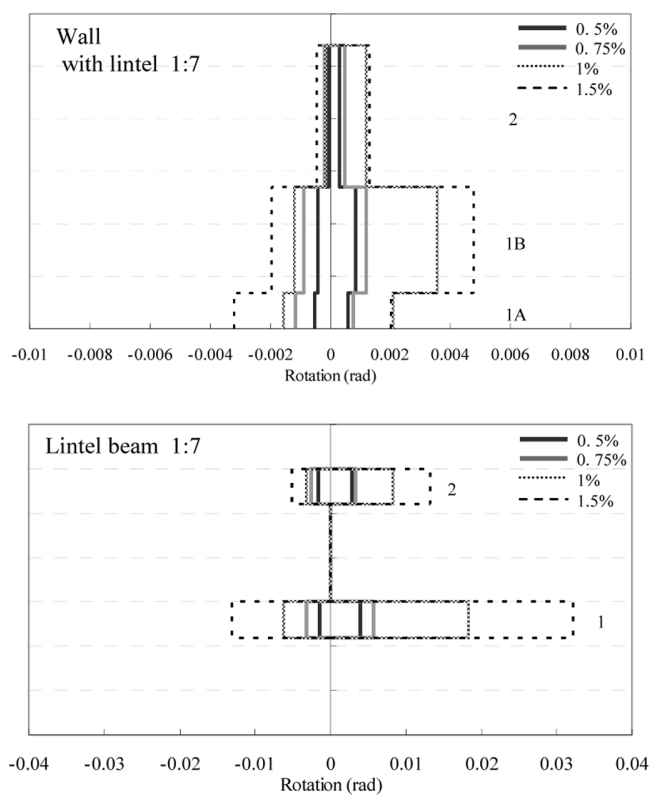

(b) $1: 7$ model

Fig. 18 Shear deformations

게 나타났다. 1 층의 회전각은 축소모델 실험체가 실물 실험체 보다 두배 정도 크게 나타났다. Fig. 15는 1 층 상 부 $3 / 4$ 영역의 대각변형과 그에 따른 전단변형을 가력 사 이클에 따라 나타내었다. 전단변형은 실물 실험체와 축 소모델 실험체가 비슷하게 나타났다. 층별 벽체 및 인방 보의 전단변형 분포는 Fig. 18에 나타내었다. 이 그림에 서 2 층의 전단변형이 1 층에 비해 축소모델의 경우 $1 / 5$ 정 도로 매우 적게 나타난 반면, 실물크기의 경우 약 $2 / 3$ 이 상의 수준을 보이고 있다. 인방보의 실물크기에서는 1 층 과 2 층 인방보가 $2 \%$ 정도의 비슷한 전단변형을 보인 반 면 축소모델에서는 1 층에서 약 $3 \%, 2$ 층에서 그의 반 정 도를 나타내고 있다. Fig. 16은 W3벽체의 1층 1/4 하부
와 $3 / 4$ 상부, 2 층에서의 휨 수직변형을 나타내었다. 1 층 (하부, 상부)과 2층의 변위가 서로 반대 방향으로 나타나 는데, 이는 실물 실험체와 축소모델 실험체에서 동일하 게 확인할 수 있다. Fig. 19에서는 인방보가 없는 경우 벽체(W2, 웨브부분)의 1 층 $1 / 4$ 하부의 휨 수직변형 분포 를 비교 하였다. 실물 실험체와 축소모델 실험체 모두 $\mathrm{W} 2$ 벽체에서 정·부방향 가력시, 분포가 유사함을 보이 고 있다. Fig. 20 은 벽체(W1, 플랜지 부분)의 1 층 밑면의 들뜸을 실물 실험체와 축소모델 실험체를 비교하여 나타 내었다. 휨 수직변형 분포와 마찬가지로 두 실험체의 경 향이 비슷함을 확인할 수 있다. W1 벽체는 정가력시 증 가하고, 부가력일 때 감소하는 형태를 보인다. 상사성에 


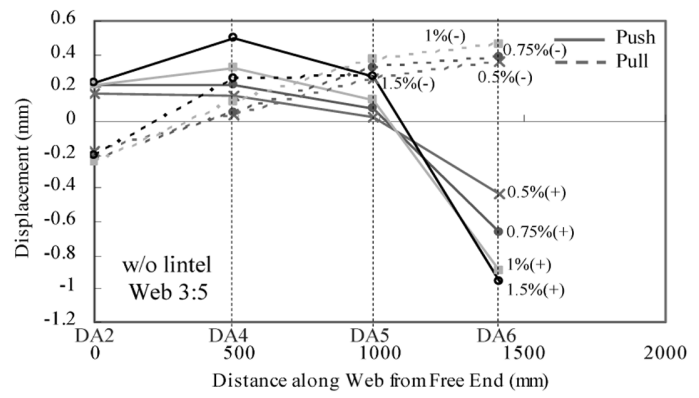

(a) 3:5 specimen

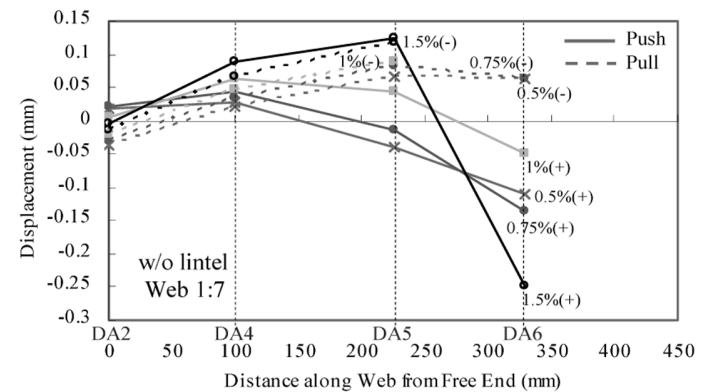

(b) $1: 7$ model

Fig. 19 Distribution of elongations in the lower quarter region of the web at 1st story (W2)

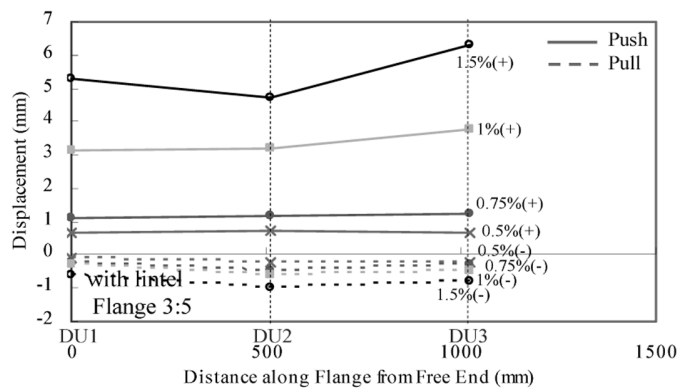

(a) 3:5 specimen

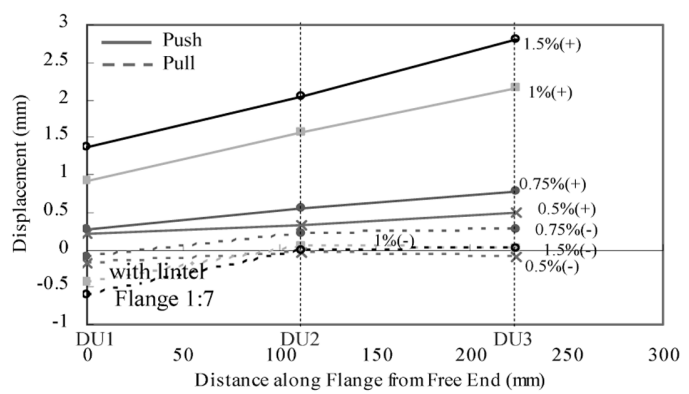

(b) 1:7 model

Fig. 20 Distribution of up-lifts along the flange at 1st story (W1)

비추어, 축소모델의 들뜸이 상대적으로 두배 정도 큼을 알 수 있다.

\section{4. 결 론}

이 연구에서는 RC벽식 부분구조의 반복 횡하중 거동 에서의 축소모델 상사성에 대해 분석 하였다. 실험 결과 분석을 통해 다음과 같은 결론을 도출할 수 있다.

1) 층변위 $1.5 \%$ 에서 실물 실험체 $(3: 5)$ 와 축소모델 실 험체가 최대강도를 발휘하였으며, 축소모델이 실물 실험체에 비해 정·부방향에서 최대강도가 29 39\% 작게 나타났다. 모델철근 주근의 항복강도가 실물 철근 주근의 항복강도에 비해 $35 \%$ 작다는 것을 감 안하면 축소모델의 상사성이 잘 맞다고 할 수 있다.

2) 연성비는 실물 실험체와 축소모델 실험체가 비슷하 게 2.5 내외였지만, 강성은 축소모델 실험체가 실물 실험체 보다 22 45\% 작게 나타났다.

3 ) 모든 실험체에서 웨브 벽체균열은 1 층 개구부 옆에 서의 휨 균열로 시작하였고, 벽체의 중앙에서는 대 각선의 전단균열이 발생하였다. 축소모델 실험체가 실물 실험체에 비해 대체적으로 벽체의 균열 폭이 크고 균열수가 적었다. 실물 실험체의 최대강도 시 파괴모드는 웨브 벽체의 우측 최하단 콘크리트 압 축파괴였으나, 축소모델 실험체에서는 기초와의 들 뜸이 밑면 전체에 걸쳐 두드러지게 나타나는 파괴 모드였다. 이러한 축소모델 실험체의 파괴모드를 개 선하기위한 추가적인 연구가 필요하다.
4) 국부거동에서 1 층 회전각은 축소모델 실험체가 실 물 실험체에 비해 크게 나타났다. 실물 실험체의 인 방보 전단변형은 고르게 나타난 반면, 축소모델 실 험체는 1 층에 집중되었다. 벽체의 전단변형, 벽체 1 층 $1 / 4$ 영역의 휨 수직변형 분포, 1 층 벽체 밑면의 들뜸 분포는 두 실험체가 비슷한 경향을 나타내었 다. 상사성에 비추어 볼 때, 축소모델의 들뜸이 더 크게 나타났다.

\section{감사의 글}

이 논문은 2009년도 정부(교육과학기술부)의 재원으로 한국연구재단의 지원을 받아 수행되었다(2010-0000789). 또한 제1저자는 고려대학교로부터 연구년(2010. 3. 1 2010. 8. 31)을 수혜 받아 이 논문을 작성할 수 있었 다. 이 모든 지원에 대해 감사드린다.

\section{참고문헌}

1. 통계청, 2005년 인구주택총조사, $2005,495 \mathrm{pp}$.

2. 이도근, 조재열, "RC기둥의 내진성능평가를 위한 재료비 선형 상사법칙," 콘크리트학회 논문집, 22권, 3호, 2010, pp. 409 417.

3. 이한선, 장진혁, “철근콘크리트 축소모델의 부재거동 상 사성에 관한 연구," 콘크리트학회 논문집, 8권, 3호, 1996, pp. $177 \sim 185$.

4. 이한선, 우성우, “철근콘크리트 축소모델의 구조거동 상 사성에 관한 실험연구,” 콘크리트학회 논문집, 8권, 6호, 
1996, 183 193.

5. 국토해양부, 대한주택공사, 아파트 주거환경 통계, 2008, $751 \mathrm{pp}$.

6. 이한선, “지진모의실험을 통한 고층 철근콘크리트 공동 주택의 내진특성 평가,” 2009 연차연구보고서, 한국연구 재단, 2009, pp. 8 83.

7. 이한선, 김상규, “프리캐스트 콘크리트 대형판 구조물의 $1 / 5$ 축소모델 제작 및 실험기법 연구," 콘크리트학회 논 문집, 8권, 2호, 1996, pp. 139 150.

8. 이한선, 장진혁, 김상규, “구조물의 축소모델 재료에 관 한 실험 연구," 대한건축학회논문집, 11 권, 9호, 1995, pp. 183 191.

9. Kim, N. S., Lee, J. H., and Chang, S. P., "Equivalent MultiPhase Similitude Law for Pseudo Dynamic Test on Small Scale Reinforced Concrete Models," Engineering Structures,
Vol. 31, No. 4, 2009, pp. 834 846.

10. 이한선, 고동우, “축소모델 철근콘크리트 보의 휨부착거 동에 있어서의 상사성," 콘크리트학회 논문집, 11 권, 3호, 1999, pp. 47 57.

11. Lu, Y., Hao, H., Carydis, P. G, Mouzakis, b. H., "Seismic Performance of RC Frames Designed for Three Different Ductility Levels," Engineering Structures, Vol. 23, No. 5, 2001, pp. 537 547.

12. Orakcal, K. and Wallace, J. W., "Flexural Modeling fo Reinforced Concrete Walls Experimental Verification," $A C I$ Structural Journal, Vol. 103, No. 2, 2006, pp. 196 206.

13. Massone, L. M., Orakcal K., and Wallace, J. W., "Modeling of Squat Structural Walls Controlled by Shear," ACI Structural Journal, Vol. 106, No. 5, 2009, pp. 646 655.

요 약 축소모델의 지진모의실험을 위해서는 실물 실험체의 구조거동을 축소모델 실험체가 잘 모사하는지 상사성 확인이 필수적이다. 본 논문에서는 2 층 $\mathrm{RC}$ 벽식구조 실험체의 반복 횡가력 실험을 통해 강도, 연성과 같은 전체거동과 휨, 전단, 들뜸과 같은 국부거동의 결과를 나타내었다. 인방보의 유무에 따른 $3: 5$ 실물 실험체와 $1: 7$ 축소모델 실험체 를 비교 분석 하였으며, $1: 7$ 축소모델 실험체가 실물 실험체의 전체거동과 국부거동에 대해서 대체로 잘 모사하고 있 음을 확인하였다.

핵심용어 : 축소모델, 상사성, 철근콘크리트, 전단벽, 인방보 